JHASS

4,5

Received 15 March 2021

Revised 2 May 2021

Accepted 5 July 2021

\section{Trump's January 6 Address: Hate Speech or Freedom of Speech? A Transdisciplinary Study}

\author{
Dalia M. Hamed \\ Department of Foreign Languages (English), Faculty of Education, Tanta University, \\ Tanta, Egypt
}

\begin{abstract}
Purpose - This research is a critical discourse analysis (CDA) of Trump's speech on January 6, 2021, which results in his supporters' storming the US Capitol in order to challenge certifying Biden's victory. The Democrats accused Trump of incitement of insurrection. Consequently, Trump was impeached. This article investigates Trump's speech to label it as hate speech or free speech.

Design/methodology/approach - Analytical framework is tri-dimensional. The textual analysis is based on Halliday's notion of process types and Huckin's discourse tools of foregrounding and topicalization. The sociocognitive analysis is based on Van Dijk's ideological square and his theory of mental models. The philosophical dimension is founded on Habermas's theory of discourse. These parameters are the cornerstones of the barometer that will be utilized to reach an objective evaluation of Trump's speech.

Findings - Findings suggest that Trump usually endows "I, We, You" with topic positions to lay importance on himself and his supporters. He frequently uses material process to urge the crowds' action. He categorizes Americans into two conflicting poles: He and his supporters versus the media and the Democrats. Mental models are created and activated so that the other is always negatively depicted. Reports about corruption are denied in court. Despite that, Trump repeats such reports. This is immoral in Habermas's terms. The study concludes that Trump delivered hate speech in order to incite the mob to act in a manner that may change the election results. Originality/value - The study is original in its tri-dimensional framework and its data of analysis.
\end{abstract}

Keywords Trump's January 6 discourse, Textual analysis, Socio-cognitive analysis, Philosophical analysis Paper type Research paper

\section{Introduction}

In the constitution of the United States of America, the First Amendment guarantees the freedom of speech, religion, press and assembly (https://constitution.congress.gov/constitution/amendment-1/). In spite of that, the Democrats accuse Donald Trump of incitement of insurrection, which means that he encourages a rebellion against the authority, after his speech on January 6, 2021.

On January 6, 2021, the Congress managed to certify President-elect Joe Biden's victory depending on the count of the electoral votes. Donald Trump delivered a speech, which resulted in his supporters' attack on the US Capitol. Trump's supporters stormed the Capitol to object to the result of the presidential elections. Accused of inciting an armed rebellion at the Capitol, Trump was impeached. Impeachment means that the House of Representatives charges Trump so that the Senate votes to acquit or convict him. Though Trump is cleared of the charge, the question about the difference between free speech and inciting speech is at issue. Is there a discourse barometer that signals the border line between freedom of speech and hate speech?

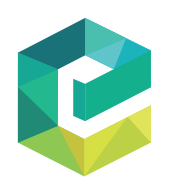

Journal of Humanities and Applied Social Sciences Vol. 4 No. 5,2022 pp. $438-456$ Emerald Publishing Limited 2632-279X DOI 10.1108/JHASS-03-2021-0055
DHA
(C) Dalia M. Hamed. Published in Journal of Humanities and Applied Social Sciences. This article is published under the Creative Commons Attribution (CC BY 4.0) licence. Anyone may reproduce, distribute, translate and create derivative works of this article (for both commercial and non-commercial purposes), subject to full attribution to the original publication and authors. The full terms of this licence maybe seen at http://creativecommons.org/licences/by/4.0/legalcode.

Conflict of interest: The author declares no conflict of interest.

The author declares that she is the sole author, no other author contributed to this paper in any form. Funding: This paper has not received any funding. 
Nancy Pelosi, the senior Democrat, declares that Trump is a danger to the nation because he is responsible, via his speech, for inciting his supporters to attack the Capitol (https://www. indiatoday.in/world/story/house-speaker-pelosi-trump-danger-america-prresidentimpeachment-us-news-1758842-2021-01-14). Trump's defense lawyers argue that Trump's use of the word "fight" is an ordinary political rhetoric (https:/www.nbcnews.com/politics/ donald-trump/trump-defense-present-case-senate-impeachment-trial-n1257601). Trump's lawyers depend on a video montage which proves that the Democrats use the word "fight" over and over in their speeches. In other words, the Democrats consider Trump's discourse to be incitingly hate speech leading to rebellion against the authority. The Republicans consider it to be free speech. Trump is cleared from the legal point of view. The research is about Trump's January 6 speech from a critical discourse analysis (CDA) perspective.

Van Dijk (2006a, b, c) considers manipulation to be an angle of power abuse and illegitimate influences. This manipulation is practiced by means of discourse, which mainly signifies unfavorable associations. Discourse manipulators make others behave in a manner that serves the manipulators' interests (Van Dijk, 2006a, b, c). Hate/manipulative speech is likely to be followed by acts of violence (Benesch, 2014). Violent behaviors are sometimes founded on fear creation. Fear is instrumentalized by social actors or organization so that the discourse of fear has become a tool of control (Altheide, 2017). Fear starts from common concerns but is transformed, via discourse repetition and exaggeration, into a belief or a way of interpreting life situations (Altheide, 2017). Fear is "an effective antidote" (Stocchetti, 2007; as cited in Wodak, 2015). Right-wing parties condemn minorities as being the cause of evils, which is called the politics of fear (Wodak, 2015). Nowadays, safety depends on the creation of fear (Hilman et al., 1990; as cited in Altheide, 2017). It seems that hate speech, fear creation and violent actions are subsequent episodes.

Discourse analysis "is no longer the concern of a single discipline" (Van Dijk, 1988, p. 23). CDA is a multidisciplinary approach which comprises diverse techniques in order to discover the way by which power abuse is enacted by discourse (Van Dijk, 1996). Hence, this study investigates Trump's speech from a transdisciplinary framework. The methodological framework incorporates three angles. The first is the textual analysis based on Huckin's discourse tools of foregrounding and topicalization (1997) and Halliday's functional linguistics and the notion of process types $(1994,2004)$. The second is the socio-cognitive analysis derived from Van Dijk's ideological square (2006a, b, 2007) and his theory of mental models $(1998,1999,2006 \mathrm{c})$. The third, the philosophical interpretation, rests on Habermas's theory of discourse $(1984,1987,1990,1996,1998)$ which pertains to social theories and philosophy. These three parameters are the cornerstones of the barometer that will be utilized in this study to reach an objective evaluation of Trump's speech. Each analytical dimension serves a certain function. The textual analysis examines the topics and the processes (verb types) of each sentence. The socio-cognitive analysis interprets the findings of the textual analysis to grasp the ideologies underneath such textual choices. The philosophical reading decodes the speech morally. The three tasks, though discrete in nature, are interwoven so that a profound appraisal of Trump's discourse may be considered.

Trump's second impeachment has led to the current research which seeks to answer these questions:

What is the accurate description of Trump's speech? Is it free speech or hate speech?

Is Trump responsible for the violence that took place after his speech on January 6 ? The research is expected to meet the aforementioned inquiries.

\section{Theoretical frameworks}

2.1 Textual frameworks

2.1.1 Huckin's discourse tools (foregrounding and topicalization). Huckin (1997) presents foregrounding and topicalization as tools that are helpful in CDA. Foregrounding is to lay

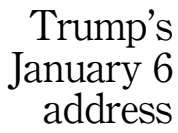

439 
JHASS 4,5

emphasis on certain discourse parts via positioning them at the beginning. Topicalization is foregrounding at the sentential level. The sentence topic refers to "what the sentence is about" (Huckin, 1997, p. 83).

2.1.2 Halliday's functional linguistics (process types). According to Eggins (2004), systemic functional linguistics (SFL) is a significant contribution to CDA. SFL is interested in the process of meaning-making through sentential constituents (Gerot and Wignell, 1994). SFL investigates the functions of linguistic elements as being produced within their contextual utterances (Donnell, 2011). Halliday $(1985,1994,2004)$ considers SFL a field decoding the scope of meaning encoded in discourse. He considers each clause to have three metafunctions: the textual (the clause as a message), the interpersonal (the clause as an exchange) and the experiential (the clause as representation).

The first metafunction, the ideational, refers to the elements in a text and the theme/rheme distinction (Halliday, 1970). The interpersonal metafunction expresses the roles and the interactions of the speakers (Halliday, 1973, 2004). The experiential metafunction, the focal point in this article, implicates the existence of actions and processes. A process is illustrated with the meaning of the main verb, so it can be a process of behaving, saying, doing, happening, sensing or being (Halliday, 1976).

Halliday (2004) explains the different types of processes. Processes relating to the external world are called material; processes relating to the inner world are mental. Process of identifying and classifying are relational process clauses. Behavioral process clauses are about external manifestations of feelings or states, verbal processes are those of saying/ meaning, and existential processes are those of being.

Material processes are those of doing. The doer, the entity who does something is the actor. The entity to whom the action is directed is the goal. Intransitive clauses contain one participant, the sctor who represents the process of happening. Mental processes are those of sensing, feeling and thinking. The senser is the entity that senses or perceives; the phenomenon is what is sensed. Relational processes are used to identify or characterize an entity.

\subsection{Socio-cognitive framework}

2.2.1 Van Dijk's ideological square. In CDA, texts and talks are of due significance due to their effect on maintaining/changing ideologies (Van Dijk, 2003). Van Dijk (2007) focuses on ideologically-based discourses that follow the general instructions of emphasizing "positive things about Us" while stating "negative things about Them" (p. 44). Van Dijk (2006a, b, 2007) presents the strategies of ideological discourse as: topicalization, actor description, categorization, irony and hyperbole. The first three are selected for this analytical study because they are mostly relevant to the data of analysis.

2.2.2 Van Dijk's theory of mental models. Discourses are social practices which produce individual, and general, ideologies (Van Dijk, 2008). Ideologies are belief systems (Van Dijk, 2000). Because ideologies are enacted in social actors' practices, Van Dijk (1998, 1999, 2006c) explains a theory that accounts for the development of ideologies via discourse. A mental model is a mediator/an interface between memory representations and individual practices. A person constructs a mental model for every experience he goes through, the model is based on the person's views regarding the intended situation. When it comes to discourse production, this mental model is the beginning. New models activate old ones so that mental models epitomize personal/subjective experiences and interpretations.

Experience models signify the personal participation and the subjective interpretation of the act an individual is involved in. Description/situation or event models refer to the person's views regarding the situations he hears about without direct involvement. Building the personal mental model needs general knowledge shared by social actors (Van Dijk, 1998, 1999, 2006c). 


\subsection{Philosophical framework}

2.3.1 Hamermas's theory of discourse (1984, 1987, 1990, 1996, 1998). Habermas, a social theorist and a philosopher, has focused on action. He postulates a discourse theory $(1984,1987)$ which focuses on rational social interactions (Feteris, 2003; Baxter, 2011). Habermas's theory relies on the social actor's efficiency to put forth the validity of his claims (https:/plato. stanford.edu/entries/habermas/). According to Habermas, social actors must observe certain credible norms for their claims to be legalized (Feteris, 2017).

Discourses, and the relevant communicative actions, become valid and justified when they are approved of by the participants involved (Habermas, 1990, 1996, 1998). Habermas explains that discourses become moral and legitimate when their consequences become clarified, which is referred to as the "moral universalizability principle (U)” (1990, p. 65).

Habermas (1987) believes that, when it comes to language, the ego anticipates a certain action from others. He explains that sentences refer to either assertion or intention. Assertoric sentences refer to the speaker's confidence that something will surely exist. Intentional sentences are about the speaker's intention to make a change in the status quo. When the hearers agree on the speaker's statement, the statement becomes powerful enough to effectuate a change through action. Habermas adds that capable speakers use intention sentences to announce actions and the expected positive/negative outcomes. With announcements, the speaker is not looking to achieve a consensus but to exert influence on the action situation" (1987, pp. 30-31).

\section{Related literature}

The study falls within the multidisciplinary approach of CDA, which attempts to explain the motives behind discursive practices, language manipulation and power abuse. CDA encompasses many tools of analysis to relate the discursive processes of text production to its interpretation (Van Dijk, 2018; Wodal and Meyers, 2009). CDA aims, to unveil the socio-cognitive implication of practices (Van Dijk, 2018). CDA proponents include Fairclough $(1992,1995)$ and Janks $(1997)$ who consider it a form of social practice.

Van Dijk's socio-cognitive approach (2006a, b, c, 2007) lays focus on mental representations behind acts. Wodak considers CDA to be part of social sciences and a problem-oriented research method (2013). Influenced by the Frankfurt School's theory of discourse, Wodak (2001) introduces the Discourse-Historical Approach (DHA) toward CDA, which is an attempt to relate between discourse and the wider macro-structure in society (Reisigl and Wodak, 2001, 2009). DHA is an interdisciplinary approach toward the analysis of discourses which mirror segregationism, especially in the representations of self and other (Reisigl and Wodak, 2001, 2009; Wodak, 1997, 2001). Hence, the representation of ingroupoutgroup relations is significant in Van Dijk' s socio-cognitive approach $(1987,1995)$ and Wodak's DHA (2001).

American political discourse has long been a subject of analysis due to its rich data. Presidential discourse, in particular, is at the center of researchers' attention because of its effect on almost all world countries. Mazid (2007) conducted a CDA of Bush's speeches following the attacks on the Pentagon. Conflicting ideologies, Us-Them discrepancy, relations of power and the resulting self-other dichotomy were the basis of analysis. Mazid (2014) explored language-power relative enactment in discourse. Notions of transitivity, modality, metadiscourse and presupposition were the cornerstones of his analytical approach. The bidirectional relation between discourse and context was highlighted through his examination of diverse texts. Mazid's belief that "we can do things with words" and that

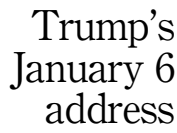


JHASS

4,5

442

"language is... the most powerful of human weapons" (2) supports the findings of this research.

Rachman et al. (2017) analyzed Trump's presidential campaign discourse in 2015. The article employs Van Dijk's thematic theory to analyze Trump's discourse. Themes were unveiled so that Trump's success in gaining power may be explained. The study was interested in the aims and the effects of Trump's utterances during his campaign.

Mcclay (2017) applied a descriptive analysis of Trump's campaign speeches. Trump's use of Us versus Them underlined his ideology and his depiction of social actors before his audiences. Chen (2018) conducted a CDA of Trump's inaugural speech. Analysis was based on Halliday's SFG. Transitivity, modality, coherence and personal pronouns were considered.

Lockhart (2018) examined Trump's Twitter rhetoric. The study demonstrates topics relevant to Trump's Twitter. Topics as marginalized groups, the media and the fake news were thought to form the majority of Trump's tweets. Garcia (2018) examined Trump's discourse from two perspectives. The first was Lakoff's strict father model; the second was the representation of otherness.

Syamwiel (2018) examined Trump's inaugural speech and concluded that Trump employed word order to affect his crowds. He maximized "We" at the expense of "I" as a politeness strategy toward his audience. He also emphasized the deterioration of the previous regime and the greatness of his, which echoed the strategy of positive self-representation and negative other representation. Gil-Bonilla (2020) analyzed some of Trump's discourses before and after his presidency. The study focused on his portrayal of immigration and ingroupoutgroup relations.

It seems that many studies attempt to describe Trump's discourse. They analyze data from one dimension or two. His inaugural discourse, his tweets, his campaign speeches and his discourse on immigration present the data of the articles dealing with Trump's discourse. Hence, this study is original regarding its data of analysis and its tri-dimensional methodological framework.

\section{Methodology}

This study is positioned within CDA. Analytical framework has three backbones. The first is the textual analysis which adopts Huckin's views on foregrounding and topicalization at the sentential level (1997). Another dimension of the textual analysis is based on functional linguistics via the detection of Halliday's process (1994, 2004). Table 1 is prepared to summarize Halliday's process types $(1994,2004)$.

The second backbone is Van Dijk's ideological square (2006a, b, 2007) and his theory of Mental Models $(1998,1999,2006$ c). Table 2 is prepared to summarize Van Dijk's ideological square and the nature of ideologically-controlled discourse.

Based on Van Dijk (2006a, b, c, 2007), Table 3 is prepared for summarize van Dijk's tools detecting ideological discourses.

This analytical stage is directed toward the socio-cognitive interpretation of the textual data. The third is based on Habermas's social theory of discourse (1984, 1987, 1990, 1996, 1998), which pertains to philosophy and sociology.

Data of analysis is Trump's speech before a gathering of his supporters on January 6 , 2021. Trump's speech transcript is downloaded from the internet (https://www.usnews.com/ news/politics/articles/2021-01-13/transcript-of-trumps-speech-at-rally-before-us-capitol-riot). The speech is manually analyzed in light of the three-parameter barometer. Analysis begins with detecting topicalization, foregrounding and the process types. After that, investigations of the ideologies and the structured mental models structured are rendered. Finally, results are interpreted in the light of Habermas's theory of discourse. So, analysis goes beyond mere textual examination. 


\begin{tabular}{|c|c|c|c|}
\hline Process type & Features & $\begin{array}{l}\text { Examples (process and participants are } \\
\text { in bold) }\end{array}$ & $\begin{array}{r}\text { Trump's } \\
\text { January } 6\end{array}$ \\
\hline Material & $\begin{array}{l}\text { Related to outer experience, actions and } \\
\text { events which happen }\end{array}$ & He (actor) wins the game (goal) & \\
\hline Mental & $\begin{array}{l}\text { Related to the inner experience (hate, } \\
\text { like) }\end{array}$ & He (senser) feels thrilled (phenomenon) & \\
\hline \multirow[t]{3}{*}{ Relational (identifying) } & $\begin{array}{l}\text { Related to the identification of the entity } \\
(\mathrm{Y} \text { is the identity of } \mathrm{X} \text { ) }\end{array}$ & \multirow{2}{*}{$\begin{array}{l}\text { He (identifier/token) is a businessman } \\
\text { (identified/value) }(\mathrm{X} \text { is } \mathrm{Y} \text { ) } \\
\text { The bag is hers. (X has Y) }\end{array}$} & 443 \\
\hline & $\begin{array}{l}\text { Intensive: } \mathrm{X} \text { is } \mathrm{Y} \\
\text { Possessive: } \mathrm{X} \text { has } \mathrm{Y}\end{array}$ & & \\
\hline & Circumstantial: $\mathrm{X}$ is at $\mathrm{Y}$ & Tomorrow is a feast ( $\mathrm{X}$ is at $\mathrm{Y}$ ) & \\
\hline \multirow{4}{*}{$\begin{array}{l}\text { Relational (classifying/ } \\
\text { attributive) }\end{array}$} & $\begin{array}{l}\text { Related to characterizing the entity ( } \mathrm{Y} \text { is } \\
\text { an attribute of } \mathrm{X} \text { ) }\end{array}$ & $\begin{array}{l}\text { Every girl (carrier) is American } \\
\text { (attribute). (X is Y) }\end{array}$ & \\
\hline & Intensive: $\mathrm{X}$ is $\mathrm{Y}$ & The girl has a guitar ( $\mathrm{X}$ has $\mathrm{Y}$ ) & \\
\hline & Possessive: $\mathrm{X}$ has $\mathrm{Y}$ & The feast will be next month ( $\mathrm{X}$ is at $\mathrm{Y}$ ) & \\
\hline & Circumstantial: $\mathrm{X}$ is at $\mathrm{Y}$ & & \\
\hline Behavioral & Related to outer manifestations & I (behaver) am smiling/sleeping & \\
\hline Verbal & Related to saying or meaning & He (sayer) tells us his story & Table 1. \\
\hline Existential & Related to the being of an entity & There is justice (existent) & Process types \\
\hline
\end{tabular}

\begin{tabular}{|c|c|c|}
\hline Us & Them & \\
\hline $\begin{array}{l}\text { Emphasize OUR positive/de-emphasize OUR } \\
\text { negative things }\end{array}$ & $\begin{array}{l}\text { De-emphasize THEIR positive/emphasize THEIR } \\
\text { negative things }\end{array}$ & $\begin{array}{r}\text { Ideologically- } \\
\text { controlled discourse }\end{array}$ \\
\hline
\end{tabular}

Discourse apparatus detecting

polarization $\quad$ Explanation

Categorization/polarization of Using discourse units as immigrants, Democrats, Republicans, etc. This is groups a necessary step paving the way for topicalizing and describing us/them Topicalization Topicalizing (bringing in the topic position) our goodness/their badness Actor description Our description (positive) against theirs (negative)

Table 3.

Discourse apparatus detecting polarization

\section{Analysis and findings}

\subsection{Textual analysis: foregrounding, topicalization and process types}

5.1.1 Foregrounding and topicalization. When a leading political figure makes an announcement before his supporters, it is expected that they will feel enthusiastic to whatever he says. They are also expected to be influenced by his selected topics. Data of analysis manifest about 200 sentences in which "I" is the foregrounded topic. The pronoun "I" refers to Trump and locates him in the subject position. Trump intends to direct the audience's attention to two points: the importance of his personality, as he is the focal point around which information revolves and the momentousness of his words.

Concentrating on "I", Trump makes his supporters zealous to know the coming news about "I". In other words, pro-Trump throngs are set in a position of captivity under the influence of the repetitive "I". After that, he begins to describe the topic "I". Consequently, process types are significant. To analyze the process means to understand the meaning of the verb related to it. 
JHASS 4,5

444

Of equal importance is Trump's deliberate use of "we" as the foregrounded topic of about 200 sentences. Trump's "we" refers to himself and his supporters as well. This is very intelligent because Trump intends to unite himself with his crowds. Accordingly, both will have the same concerns, fate and future. This technique invites his supporters to act and react passionately. Trump's masses become a center of attention as his speech is about them and for their own sake. That is why he uses "You" as a topic about 100 times. The coming sub-sections present the analysis of processes pertaining to the predominant foregrounded-topics: "we", "I" and "You". 5.1.2 Process types. 5.1.2.1 "We" processes. Trump's use of material processes pertaining to "we" as the sentence topic/actor widely surpasses other process types. This is a signal of his will to convince his supporters of their ability to act and make a change. Material processes deal with doings and actions. Trump and pro-Trump crowds are presented as being actors who are powerful enough to change the status quo. This, in turn, implants the belief that they are able to move and carry out whatever they decide on whenever there is a motive to do so. Hence, Trump employs material processes to offer the stimulus behind future actions. The sentential-foregrounded topic "we" is the actor and the topic followed by a series of goals related to Trump's triumph in the presidential elections. The following sentences have the structure actor/topic-material process of doing-goal:

We will not take it (fraud) anymore.

We will stop the steal.

We won this election.

We won it by a landslide.

We will not let them silence your voices.

We are not going to let it happen.

We're leading Pennsylvania, Michigan, Georgia.

We win the presidency.

We will not be intimidated into accepting the hoaxes and the lies.

We've amassed overwhelming evidence about a fake election.

We lay out the case for the entire world.

We won Wisconsin.

We must stop the steal.

These are sentences of doings in which the doers, Trump and his supporters, have to make further actions in order to protect their victory in the American Presidential elections. Trump's use of "We" is intended to make the audience feel responsible for protecting the election results because these results are theirs, not Trump's. So, a noble motive is set so that pro-Trump supporters will be united behind it.

Material processes of happenings have the actor without a goal. These processes describe an event, the state that he wins, his supporters win and they both must work continuously secure their achievement. The following sentences have the structure actor/topic-material process of happening:

We will never give up.

We will never concede.

We did not lose. 
These intransitive processes serve the same reason as the transitive ones: to present a motive for further action. Defending the presidential elections is a virtuous motive which Trump succeeds in making the supporters gather around. Processes of happenings intensify Trump's conviction that he is the winner of the American Presidency. This is Trump's first step.

Trump's second step is to endorse the people's sense of their capability of taking measures. To be included in positive acts is to be considered powerful. Material process of doings aim to make the crowds feel effective and energetic. For this reason, actor-material process of doing-goal structure appears again to support the people's sense of leverage:

We've created the greatest economy.

We rebuilt our military.

We get you the biggest tax cuts in history.

We got you the biggest regulation cuts.

We created Space Force.

We did things that nobody ever thought possible.

We've saved tremendous amounts of money.

We've done too much.

We got rid of the ISIS caliphate.

We built the greatest political movement.

The third step is to offer the required action. Trump uses material processes of happenings to explain what will happen next. Actor/topic-material process of happening structure presents the alternative solution:

We're going to have to fight.

We're going to walk down.

We're going to walk down to the Capitol.

We're out here fighting.

We'll take care of going forward.

We fight.

We fight like hell.

And we're going to try.

He also provides the results of his call to fight via action process:

Together, we will drain the Washington swamp.

We will clean up the corruption in our nation's capital.

We're going to walk down Pennsylvania Avenue.

And we're going to the Capitol.

We're going to try.

Relational processes outnumber mental processes, though both come in the second rank after the material processes. This is an appropriate choice because Trump wants to change the 
JHASS

4,5

446

actual news about Joe Biden's victory. Trump needs a discourse which moves the mobs. Mental processes refer to inner experiences; relational processes are about characterization of entities. Trump is more concerned with the outer experience. Consequently, few examples of mental and relational processes are detected. Examples of mental processes, senser- mental process-phenomenon structure, include:

We're supposed to protect our country.

We must ensure that such outrageous election fraud never happens again.

We love our country.

Together, we are determined to defend and preserve government of the people.

These examples present an inner and an ethical motive to make the crowds follow Trump's directions.

Relational processes are used to describe the crowds as in:

We have hundreds of thousands of people here (Possessive Relation: Carrier-Attribute).

We are the greatest country (Intensive Relation: Identified-Token).

We have truth and justice on our side (Possessive Relation: Carrier-Attribute).

We have a deep and enduring love for America (Possessive Relation: Carrier-Attribute).

We have overwhelming pride in this great country (Possessive Relation: Carrier-Attribute).

Descriptions seem to be emotive. This may be a technique to stir people's sense of loyalty to America. Trump describes the media as being the source of evils. Based on electoral counting, the media announce Biden's victory. Trump endeavors to change the facts announced by the media. As a result, it is not surprising that he deforms the media:

We do not have a free and fair press (Possessive Relation: Carrier-Attribute).

We have a corrupt media (Possessive Relation: Carrier-Attribute).

We do not have a fair media (Possessive Relation: Carrier-Attribute).

5.1.2.2 "I" processes. Material processes are numerous. This time, they center on Trump's sole doings. Trump is not satisfied with announcing his issue using "we". He declares the same issue using the first-person singular pronoun "I", which refers to Trump the actor and the doer. He, first, explains the motives behind his speech and his demands via actor-material process of doing-goal structure. For example:

I've never seen anything like it (media fraud).

I will lay out just some of the evidence (about his victory).

I won them (elections) both.

I won (this election) much bigger than the first.

I'm not going to let it (fraud) happen.

I'm going to read you pages (about media fraud).

I could go on and on about this fraud that took place in every state.

I could go on for another hour reading this stuff (fraud) to you. 
He also explains his future actions in "I'd fight", which is a material process without a goal. This refers to Trump's determination to fight whoever challenges him: the media, the Democrats or the Republicans themselves.

Trump's use of mental processes aims to express his desires. Examples are fewer than the material ones. Senser-phenomenon structure includes:

I just want them (his supporters) to be recognized by the fake news media.

I just really want to see what they (the media) do.

I just want to see how they (the media) covered.

Trump introduces himself as being a victim of the media. He explains his gratitude for the crowds "I want to thank you (supporters), I want to thank you for the extraordinary love." He also expresses his strong confidence in his supporters' observance to his directions "I know that everyone here will soon be marching over to the Capitol." He does not forget to arouse the people's emotions by saying "I love you". As a result, mental processes are intended to endorse the action of "fight". Words about love, confidence and emotion help in producing a deeper effect. This effect is to motivate the crowds to act as Trump requires.

Relational processes are few. Two examples are remarkable. The first is Trump's description of his honesty by saying "I am honest", so the crowds may believe in whatever he says. The second is his declaration that he will join his supporters at the Capitol "I'll be there with you", which never happens.

5.1.2.3 "You" processes. "You", referring to pro-Trump's supporters, is used in the topic position less than "we" and "I"."You" is pointed directly to pro-Trump's supporters. Addressing his supporters via "You", Trump makes them responsible for the consequences in case that they do not act as required. "You" is deliberately utilized so that the crowds feel that it is their obligation to initiate an action. Material and relational processes prove Trump's determination to make his supporters act under the surge of ethical and national responsibility. So, it is expected to find utterances as "You do not concede when there's theft involved, Many of you have traveled from all across the nation to be here." When a person knows about an illegal act and steps back, this person is accused of being wicked. When a person knows that his fellows travel to participate in an event and he simply withdraws, this person is considered to be vicious. Accordingly, Trump accuses his masses of being malicious in case that they retreat and go home. He also menaces them of a dark future if they do not continue challenging the election results: "if you do not fight like hell, you're not going to have a country anymore." These examples are material processes of happenings. They aim to urge the mob to continue their revolt against Biden's victory.

Material processes of doings are uttered in a tone reflecting necessity:

You have to get your people to fight.

You have to show strength.

You have to protect our Constitution.

You cannot vote on fraud.

Trump threatens his supporters that if they do not follow his orders and fight, their future will be in danger "You could have changed the whole thing, If you do not do that, that means you will have a president of the United States (Biden) for four years, with his wonderful son (Hunter)." Trump's supporters are, consequently, caught between two choices: going home or fighting. If they concede and return home, they will act in an unethical manner.

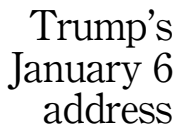


JHASS

4,5

448

Their recession will endanger America, as Trump declares. If they fight, they will protect the country, the constitution and the future. Hence, they will be moral patriots.

Mental processes are predominantly about the masses' knowledge "You know". Trump repeatedly addresses his supporters telling them "You know". This short statement serves the purpose intended by material processes. As long as the masses know, they are responsible for the negative results to follow in case that they do not obey Trump's orders. It is obvious that Trump does not mention the phenomenon, the entity or the topic known by the masses. This deliberate deletion of the phenomenon observed generalizes it so that it may refer to anything. This, in its turn, makes the audience feel more responsible because they know. When someone knows, he cannot evade duty. Trump's frequent use of "You know" indicates that he considers the masses to be in charge of what will follow if they do not act and react as required.

As far as relational processes are concerned, they push the crowds to be more activated. Relational/attributive processes as "You are stronger, You are smarter" make the crowds believe in their ability to act and remove any doubt about their abilities. The comparative form means that pro-Trump's supporters are stronger and smarter than the others, the Democrats or Biden's supporters. Relational/identifying process as "you're the real people, you're the people that built this nation, You're not the people that tore down our nation" serve to exert more pressure on the masses as they have to fight because they are the "real people", which means that the Democrats are the fake citizens. Relational/possessive processes threaten pro-Trump's crowds of negative consequences if they do not follow him: "You will have a president (Biden) who lost all of these states, you will have a president (Biden), to put it another way, who was voted on by a bunch of stupid people who lost all of these states."

Trump's use of "We, I, You" as the sentential-foregrounded topics covers the whole speech. It is rare to find another sentential topic. The whole speech repeats the same ideas over and over. These ideas are expressed by sentences which contain "we" as the foregrounded topic, referring to Trump and his mob. The same ideas are expressed by "I" as the topic, referring to Trump and by "You" as the foregrounded topic, which refers to the crowds. Trump's discourse lays responsibility on the people to change the election results, otherwise; the future will be dark and pessimistic.

\subsection{The socio-cognitive analysis: Van Dijk's ideological square and mental models}

5.2.1 Van Dijk's ideological square. Texts are where ideologies are positioned (Fairclough, 2010). So, this level of analysis interprets the findings of the textual level regarding the ideologies implanted and activated by textual elements. Being mental representations (Van Dijk, 2006c), ideologies control the way people view the news and the actions, verbal or physical, which follow. Van Dijk's ideological square centers on the idea that ideological discourse signals positive representations of the self and negative representations of the other. This self-other dichotomy can be detected via different technique such as categorization, topicalization and actor description (Van Dijk, 2006a, b, c, 2007).

Categorization depends on the creation of opposing poles or conflicting categories. Trump creates three main categories. The first is the people or his supporters. The second is that of the media or the big tech. The third is the Democrats or their representatives such as Joe Biden. Trump puts himself in the first category, that of the people. So, Trump's discourse manifests Trump and his crowds referred to as "We". Whenever he says "We", reference pertains to Trump and his masses. The media and the big tech are referred to by "they", and so are the Democrats. These three categories are the basic structure of Trump's discourse. Though Trump mentions a fourth category, the weak Republicans, his descriptions regarding it is not as negative as that related to the Democrats and the Media. In this concern, 
analysis centers on Trump and his supporters (We) against the media and the Democrats (They).

Topicalization is investigated in the first section of the analysis. Trump positions himself and his supporters in the topic position and endows this topic with activities via the material processes of doing and happening. This means that Trump, whose speech generally puts Trump and/or his supporters in the topic position, considers himself and his Allies as the sole active actors capable of making an effect. Positioned as the active agents/actors and the foregrounded topic, the actor description is at issue.

Actors, Trump and/or his supporters, are represented via positive descriptions. Words associated with Trump and/or his supporters trigger favorable mental images. Words associated with the media and the Democrats display unfavorable traits. As a result the opposing two categories are described in a manner that highlights OUR positive traits versus THEIR negative trains, or US versus THEM. Throughout Trump's speech, he always repeats the positive features pertaining to WE/US, the first category. On the other hand, Trump always portrays the other two categories, the media and the Democrats, via negative terms. The media and the Democrats are depicted as being corrupt and conspiring against the constitution. Trump and his supporters are characterized as being honest, patriots and active agents. For example:

We beat them (the media).

We surprised them (the media).

I'm honest.

(You are) American patriots who are committed to the honesty of our.

With your help over the last four years, we built the greatest political movement.

With your help, we will finally pass powerful requirements for voter ID.

Together, we will drain the Washington swamp and we will clean up the corruption in our nation's capital.

We are the greatest country on Earth.

We have truth and justice on our side. We love our country.

We have overwhelming pride in this great country.

Together, we are determined to defend and preserve government of the people, by the people and for the people

The other category, the media, is always represented by elements which trigger negative images related to cheating and deception. Moreover, many sentences foreground the media malpractices. For example:

The media is the biggest problem.

The fake news and the Big tech (are the biggest problem).

We took them (the media) by surprise and this year they rigged an election.

They (the media) rigged it like they've never rigged an election before.

And (election) stolen by the fake news media.

Our media is not free, it's not fair.

It (the media) suppresses thought, it suppresses speech and it's become the enemy of the people. 
JHASS

4,5

450

It's (the media) the biggest problem.

The media has constantly asserted the outrageous lie that there was no evidence of widespread fraud.

The American people do not believe the corrupt, fake news anymore.

They (the media) have ruined their reputation.

Twitter's bad news.

Instances which background the media but describe it negatively include:

I just want them to be recognized by the fake news media.

I just want to see how they (the media) covered.

We do not have a free and fair press.

We have a corrupt media. They've gone silent. They've gone dead (about Hunter's misdeeds).

We do not have a fair media anymore.

The people who want to deceive ... Big tech, media.

The third category, the Democrats, is as negatively described as the media. The Democrats are described as being deceitful and misleading, Except for the last example, the examples below foreground the Democrats' duplicity:

Democrats have gotten away with election fraud.

Democrats attempted the most brazen and outrageous election theft ... So pure theft.

They (the Democrats)'re ruthless.

And how come Joe is allowed to give a billion dollars of money to get rid of the prosecutor in Ukraine.

Corrupt Democrat-run cities deployed more than 500 illegal, unmanned, unsecured drop boxes.

They (the Democrats) want to steal the election.

The Democrats are hopeless.

All of us here today do not want to see our election victory stolen by emboldened radical-left Democrats.

The aforementioned examples highlight the three categories and the descriptions ascribed to each category.

5.2.2 Van Dijk's mental models. Trump succeeds in creating two polarized categories, WE/US against THEY/THEM. Via emphasizing his and his supporters' positive traits against the media and the Democrats' negative traits, he establishes an ideology about OUR goodness versus THEIR corrupt. The ideology forms a motivation so that the crowds may act for the sake of America. Trump seeks to model the people's perception of facts. He endeavors to make the crowds believe in his righteousness and in the Democrats and the media's dishonesty. In other words, he pursues to set polarized mental models.

Discourse is a source of mental models. A person sets a mental model according to his perception to every discourse element. The mental models control the manner in which the person acts. Trump's discourse presents many incidents and events regarding the Presidential elections. He negotiates them from his personal view-point and expresses them in a manner that imposes his personal interpretation of events. In doing so, he attempts 
to create mental models in his supporters. Trump's supporters generate, under the effect of his discourse, situation/event models because these models are about events they hear about.

Trump frequently repeats ideas about the WE/US-THEY/THEM polarization and opposing features. This results in enforcing the related event models in his supporters. Consequently, the masses will conceive of the events according to Trump's own interpretation of them, Trump's biased mental models. Positioning Trump and/or his supporters as the foregrounded topic, employing material processes to promote active procedures, emphasizing Trump's goodness, emphasizing the crowd's patriotism, deforming the media, representing the Democrats negatively, Trumps aims to fix a biased mental/event model in his masses. This biased model is the stimulus inducing the crowds to fight the vicious category.

\subsection{Habermas's theory of discourse}

The final step of analysis is founded on the basis of Habermas's discourse theory (1984, 1987). Analysis starts with textual features, foregrounding and topicalization, and moves to the socio-cognitive feature, through van Dijk's ideological square and mental models. Previous analytical tools prove Trump's bias against the media and the Democrats. He uses discourse aids to expose the threat surrounding America. The only way out, as he suggests, is to fight. In Habermas's views, Trump's discourse is not a goal per se; it aims to make the audience interact. Trump's discourse, according to Habermas, is the motivating force behind the masses' actions. Habermas put some conditions for a discourse to be moral. The most important one is the explanation of the consequences. Trump does not illuminate what is meant by "fight" or what happens after going to the Capitol.

The credibility of facts is significant in Habermas's theory. When it comes to Trump's narration of the reports about election theft, no single evidence is authenticated by any court. From Trump's personal opinion, he reports facts about election fraud. From the legal platform, he tells lies. Based on Habermas's theory, Trump's act is neither moral nor legal.

Sentence types are also significant. Trump reports many assertoric sentences. All his sentences about election fraud, media corruption and the Democrats' evil are assertoric. He considers that these things exist. The very sentences are not mere announcements of the status quo and its deteriorating state. Trump has an intention behind uttering these gloomy declarations about fraud and election theft. Trump wants to push the crowds to make a change. His assertoric sentences are intentional as well, they intend to actuate the crowds and drive them to make whatever may change the election results. Trump's intention is straightforwardly uttered in all his sentences in which he calls the people to fight and walk to the Capitol. Trump utters intentional sentences so that the mob may be stimulated to challenge the election results. Trump's announcements prove to be powerful enough to make the people invade the Capitol.

\section{Discussion}

This analytical/tri-dimensional study investigates Trump's January 6 speech, the speech which results in his supporters' March on the US Capitol to defy the certification of Biden's electoral victory. The Democrats accuse Trump of putting pressure on the crowds, inciting them and instigating a rebellion against the constitution he swears to protect. Trump's speech aims to delegitimize the American Presidential election and undermine its credibility because results prove Biden's triumph. Trump's lawyers consider his speech to be free speech protected by The Constitution. Hence, this study tries to examine Trump's discourse from a critical perspective in order to answer a question about Trump's discourse nature.

\section{Trump's January 6 address}


JHASS 4,5

452

The study is tri-dimensional. The textual dimension detects Trump's use of "I, We, You" as the foregrounded topics. Trump concentrates on the crowds and places them in the topic position via his use of "We" and "You". He also centers on himself via locating "I" in the topic location. This means that "We", "I" and "You" are the backbones of Trump's discourse. Another textual component is the material processes of doings and happenings. They negotiate Trump's intention that he aims to effectuate actions causing changes. That is why relational and mental processes are not widely used. The processes associated with the topics indicate the material acts anticipated on the part of the crowds. Processes reflect America's supposed state of danger and Trump's threat if the crowds do not act. The topics and the process lay the motive stimulating the crowds to revolt: saving America.

The socio-cognitive dimension presents the ideological foundation behind the topics and the processes detected. Trump justifies his call to fight by creating a polarized description which divides the American society into two differing poles: Trump and pro-Trump's supporters versus the media and the Democrats. He deliberately represents the American society in the form of opposing categories. The good category pertains to Trump and his supporters who are always described in favorable terms; this is the category of ingroups/WE. The evil category pertains to the media and the Democrats who are always deformed; this is the outgroups or THEY. Mental models are created under the influence of Trump's words. These models are activated whenever Trump refers to "WE" or "I" in positive discourse items, and signals "THEY" in negative items. The models are established, operated and energized so that the crowds behave in a manner that underlines the WE-THEY divergence/polarization. The categories Us versus Them, the positive descriptions pertaining to Us and the negative traits ascribed to Them-all serve to set a mental image of America as being conspired against. This works with the selected topics and process to prompt the crowds to revolt and save their country.

The philosophical dimension interprets the results of the textual and the socio-cognitive from a moral view-point. Trump does not clearly explain the outcomes of his call to fight; neither does he present any legal evidence of fraud. He also does not join the crowds as he promises. Hence, his act seems immoral. He intends to make the crowds act without offering a valid claim for that act.

Trump pursues actions and interactions. He strives to make actions the only way out of a pessimistic future. So, he repeats over and over that to fight is the solution to America's dilemma. When the crowds invade the Capitol to rescue America from the wicked clutches of the media and the Democrats, they are not to be blamed. Analysis suggests that Trump's discourse is full of negative associations toward the Democrats and the media. His discourse divides Americans into conflicting groups. Ingroup-outgroup relation is that of iniquity, the outgroup harms and damages the ingroup by forcing an illegitimate election. These interpretations are the epitome of Trump's discourse. Trump is thought to be blamed for generating discourse which sets social divisions and implants hatred among social members.

Analysis presents examples of Trump's attempt to create fear. He depicts a gloomy future in case that Biden becomes the president. He keeps on repeating unfavorable descriptions regarding the media and the Democrats. The crowds are expected to feel fear regarding their country. When fear controls, people may act violently. The resulting violence is expected to follow the speech associated with negative descriptions, hate speech.

Free speech has nothing to do with categorizations, distortion of social members and politically-biased polarization. Free speech has nothing to do with lies and rumors. Trump reports numbers to prove election fraud, though the American legal institutions deny the numbers. Trump promises to March on the Capitol to join the crowds, yet he does not. The Senate does not condemn Trump, but discourse analysis seems to do.

This study is original in the sense that it combines three approaches in order to render an objective and an accurate analysis of Trump's discourse. Habermas's theory of communicative act is usually employed in legal discourses. This article proves that 
Habermas's discourse theory can be used to analyze political discourse. Incorporating Habermas's theory with van Dijk's endows the textual analysis with deeper interpretations.

\section{Trump's January 6 address}

\section{Conclusion}

The main purpose of this study is to define Trump's speech on January 6, 2021. The article tries to label the speech so that it may be described as being hate speech or free speech. In order to render an objective and an accurate analysis, a tri-dimensional model of CDA is prepared for this study. The model depends on three analytical dimensions pertaining to three disciplines. So, the study is transdisciplinary. The first analytical perspective is the textual analysis, the second is the socio-cognitive interpretation and the third has to do with philosophically-derived notions. Consequently, Huckin, Hallidy, Van Dijk and Habermas's postulates are comprised so that the study is thought to be unbiased, precise and in-depth. Trump's January 6 discourse is analyzed in the light of the transdisciplinary/tri-dimensional framework.

Textual analysis proves that Trump centers his speech on himself and/or his supporters and they both are endowed with foregrounding and topicalization. Trump and his supporters are mainly associated with material processes. This refers to his intention to issue an action. Cognitive analysis manifests Trump's continuous technique of positive Self-representation and negative Other-representation, where the Self refers to Trump and his supporters and the Other refers to the media and the Democrats. Moreover, Trump creates negative mental images about the Other and always activates these mental models via his repeated distortions of the media and the Democrats. Dividing American into two conflicting poles and dignifying one while deforming the other, Trump's discourse implants hatred in one social category against the other.

Habermas's philosophical notions about valid discourse are rarely found in Trump's. Trump's discourse consequences are not clarified as he urges the crowds to march on the Capitol without telling them the careful outcomes resulting from that act. Trump promises to join the crowds when they proceed to the Capitol but never does. Trump reports many numbers about the forgery and the falsification in the US Presidential elections, but no single court approves of any case against the election credibility. Trump's discourse, filled with announcements, is about his intention to push an action that may change the status quo. From this research's view, Trump's speech is not thought to be free speech. It seems to be hate speech which aims to manipulate the crowd's enthusiasm and sensations so that they may be induced to act in a manner which serves his personal advantage. When discourse associates actors with processes of doings without valid reasons, sets polarized categories, deforms certain categories, causes fear and presents claims without authentic facts, it cannot be considered free speech.

\section{References}

Altheide, D.L. (2017), Creating Fear: News and the Construction of Crisis, Routledge, London and New York.

Baxter, H. (2011), Habermas: The Discourse Theory of Law and Democracy, Stanford University Press, California.

Benesch, S. (2014), "Defining and deminishing date dpeech: state of the world's minorities and indigenous peoples", available at: https:/minorityrights.org/wp-content/uploads/old-sitedownloads/mrg-state-of-the-worlds-minorities-2014-chapter02.pdf.

Chen, W. (2018), "A Critical discourse dnalysis of Donald Trump's inaugural speech from the perspective of systemic functional grammar", Theory and Practice in Language Studies, Academy Publications, Vol. 8 No. 8, available at: https://www.academypublication.com/ojs/ index.php/tpls/issue/view/68. 
JHASS 4,5

Donnell, M. (2011), "Introduction to systemic functional Linguistics for discourse analysis", available at: https://docplayer.net/21273180-Language-function-and-cognition-2011-12-introduction-tosystemic-functional-linguistics-for-discourse-analysis.html.

Eggins, S. (2004), An Introduction to Systemic Functional Linguistics, 2nd ed., Continuum, New York and London.

Fairclough, N. (1992), Discourse and Social Change, Polity press, Cambridge.

Fairclough, N. (1995), Critical Discourse Analysis: The Critical Study of Language, Longman, London.

Fairclough, N. (2010), Discourse Analysis: The Critical Study of Language, 2nd ed., Longman, Harlow.

Feteris, E.T. (2003), "The rationality of legal discourse in Habermas's discourse theory", Informal Logic, Vol. 23 No. 2, pp. 139-159.

Feteris, E.T. (2017), Fundamentals of Legal Argumentation: A Survey of Theories on the Justification of Judicial Decisions, 2nd ed., Argumentation Library, Springer.

Garcia, T.M. (2018), "Donald J. Trump: a critical discourse analysis", available at: https://www. researchgate.net/publication/327441199_Donald_J_Trump_A_Critical_Discourse_Analysis_ Donald_J_Trump_un_analisis_critico_del_discurso.

Gerot, L. and Wignell, P. (1994), Making Sense of Functional Grammar, Gerd Stabler, Queensland.

Gil-Bonilla, J.F. (2020), "Critical discourse analysis of Trump across time”, available at: file://C:/Users/ DELL/Downloads/[23352027\%20-\% 20Sustainable \%20Multilingualism] $\% 20$ Critical $\%$ 20Discourse $\% 20$ Analysis $\% 20$ of $\% 20$ Trump $\% 20$ Across $\% 20$ Time $\% 20(1)$.pdf.

Habermas, J. (1984), The Theory of Communicative Action: Reason and Rationality of Society, Beacon Press, Boston, Vol. 1.

Habermas, J. (1987), The Theory of Communicative Action: Lifeworld and System, a Critique of the Functionalist Reason, Vol. 2, Bacon Press, Boston, (Translated by Thomas McCarthy).

Habermas, J. (1990), Moral Consciousness and Communicative Action, The MIT Press, Cambridge and Massachusetts.

Habermas, J. (1996), Between Facts and Norms: Contributions to a Discourse Theory of Law and Democracy, (W. Rehg, Trans.), MIT Press, Cambridge.

Habermas, J. (1998), On the Pragmatics of Communication, in Cooke, M. (Ed.), MIT Press, Cambridge and Massachusetts.

Halliday, M.A.K. (1970), "Language structure and language function”, in Lyons, J. (Ed.), New Horizons in Linguistics, Penguin, Harmondsworth.

Halliday, M.A.K. (1973), Explorations in the Functions of Language, Edward Arnold, London.

Halliday, M.A.K. (1976), "Functions and universals", in Kress, G. (Ed.), Halliday: System and Function in Language, Oxford University Press, London, pp. 26-35.

Halliday, M.A.K. (1985), An Introduction to Functional Grammar, Edward Arnold.

Halliday, M.A.K. (1994), An Introduction to Functional Grammar, Edward Arnold.

Halliday, M.A.K. (2004), An Introduction to Functional Grammar, 3rd ed., Hodder Arnold.

Huckin, T. (1997), "Critical discourse analysis", in Miller, T. (Ed.), Functional Approaches to Written Texts: Classroom and Application: English Language Programs, United States Information Agency, ERIC, Washington, DC.

Janks, H. (1997), "Critical discourse analysis as a research tool", Discourse: Studies in the Cultural Politics of Education, Vol. 18 No. 3, pp. 329-342.

Lockhart, M. (2018), President Donald Trump and His Political Discourse: Ramifications of Rhetoric via Twitter, Taylor \& Francis Group, Routledge, New York.

Mazid, B.M. (2007), "Presuppositions and strategic functions in Bush's 20/9/2001 speech: a critical discourse analysis", Journal of Language and Politics, Vol. 6 No. 3, pp. 351-375, doi: 10.1075/jlp.6. $3.05 \mathrm{maz}$. 
Mazid, B.M. (2014), CDA and PDA Made Simple. Language, Ideology and Power in Politics and Media, Cambridge Scholar Publishing.

Mcclay, R. (2017), "Us and them: a descriptive analysis of Donald Trump's campaign speeches", available at: https://www.birmingham.ac.uk/Documents/college-artslaw/cels/essays/ appliedlinguistics/McClay2017.Trump-Speech-Discourse-Analaysis.pdf.

Rachman, A., Yunianti, S. and Ratnadewi, D. (2017), "Critical discourse analysis in Donald Trump presidential campaign to win American's heart", TELL Journal, Vol. 5 No. 2, available at: https://core.ac.uk/download/pdf/229568964.pdf.

Reisigl, M. and Wodak, R. (2001), Discourse and Discrimination: Rhetorics of Racism and AntiSemitism, Routledge, London.

Reisigl, M. and Wodak, R. (2009), "The discourse-historical approach", in Wodak, R. and Meyer, M. (Eds), Methods of Critical Discourse Analysis, 2nd ed., Sage, London.

Syamwiel, A. (2018), "Propaganda on Donald Trump inaugural speech: a critical discourse analysis", available at: http://digilib.uin-suka.ac.id/31511/2/12150058_BAB\%20I_BAB_TERAKHIR_ DAFTAR_PUSTAKA.pdf.

Van Dijk, T.A. (1987), Communicating Racism: Ethnic Prejudice in Thought and Talk, Sage, Newbury, CA.

Van Dijk, T.A. (1988), News as Discourse, Lawrence Erlbaum Associates, Hillsdale, NJ.

Van Dijk, T.A. (1995), "Discourse semantics and ideology", Discourse and Society, SAGE Publications, Vol. 6 No. 2, doi: 10.1177/0957926595006002006.

Van Dijk, T.A. (1996), "Discourse, power, and access", in Caldas-Coulthard, C.R. and Coulthard, M. (Eds), Texts and Practices: Readings in Critical Discourse Analysis, Routledge, London.

Van Dijk, T.A. (1998), Ideology: A Multidisciplinary Approach, SAGE Publications, London.

Van Dijk, T.A. (1999), "Context models in discourse processing”, in van Oostendorp, H. and Goldman, S.R. (Eds), The Construction of Mental Representations During Reading, Erlbaum, Mahwah, NJ.

Van Dijk, T.A. (2000), "Ideology and discourse: a multidisciplinary introduction", available at: http:// www.discourses.org/UnpublishedArticles/Ideology \%20and\%20discourse.pdf.

Van Dijk, T.A. (2003), "Political discourse and ideology", available at: http://www.discourses.org/ OldArticles/Political\%20Discourse \%20and\%20Ideology.pdf.

Van Dijk, T.A. (2006a), "Politics, ideology, and discourse", in Brown, K. (Ed.), The Encyclopedia of Language and Linguistics, Pergamon Press, Oxford, New York, Vol. 9.

Van Dijk, T.A. (2006b), "Ideology and discourse analysis", Journal of Political Ideologies, Routledge. Taylor Francis Group, Vol. 11 No. 2, pp. 115-140.

Van Dijk, T.A. (2006c), "Discourse and manipulation", Discourse and Society, SAGE Publications, Vol. 17 No. 3, pp. 359-383.

Van Dijk, T.A. (2007), "Ideology and discourse: a multidisciplinary introduction”, available at: http:// www.discourses.org/UnpublishedArticles/Ideology \%20and\%20discourse.pdf.

Van Dijk, T.A. (2008), "News, discourse, and ideology", available at: http://www.discourses.org/ OldArticles/News, \%20Discourse \%20and\%20Ideology.pdf.

Van Dijk, T.A. (2018), "Socio-cognitive discourse studies”, in Flowerdew, J. and Richardson, J.E. (Eds), The Routledge Handbook of Critical Discourse Studies, Routledge.

Wodak, R. (1997), "Others in discourse, racism and anti semiticism in present day Austria”, Research on Democracy and Society, Vol. 3, pp. 275-296.

Wodak, R. (2001), "What is CDA about: a summary of its history, important concepts and its developments", in Wodak, R. and Meyer, M. (Eds), Methods of Critical Discourse Analysis, SAGE Publications, London.

\section{Trump's January 6 address}


JHASS 4,5
Wodak, R. (2013), "Critical discourse analysis: challenges and perspectives", in Wodak, R. (Ed.), Critical Discourse Analysis: Concepts, History, Theory, SAGE Publications, Los Angeles, London, New Delhi, Singapore and Washington DC.

Wodak, R. (2015), The Politics of Fear: What Right-Wing Populist Discourses Mean, SAGE Publications.

Wodak, R. and Meyer, M. (2009), "Critical discourse analysis: history, agenda, theory, and methodology", in Wodak, R. and Meyer, M. (Eds), Methods of Critical Discourse Analysis, SAGE, London.

\section{Corresponding author}

Dalia M. Hamed can be contacted at: daliahamed53@yahoo.com

For instructions on how to order reprints of this article, please visit our website: www.emeraldgrouppublishing.com/licensing/reprints.htm Or contact us for further details: permissions@emeraldinsight.com 